\title{
Emotional Intelligence among Nursing students - An Integrated Review
}

\author{
Deepa Shaji Thomas ${ }^{1} \mathrm{Msc}(\mathrm{N})$, JansiRani Natarajan ${ }^{2} \mathrm{Msc}(\mathrm{N})$ \\ ${ }^{1}$ Lecturer, Maternal and Child health Nursing College of nursing, Sultan Qaboos University, \\ ${ }^{2}$ Lecturer, Fundamentals of Nursing and Administration College of nursing, Sultan Qaboos University, \\ P.O.Box.No.66, Al-Khoud, Muscat, Sultanate of Oman.
}

\begin{abstract}
Background: Emotional intelligence of nursing students can be enhanced and empowered for social and academic adjustments. Purposes: This article explores the published evidence on the level of Emotional Intelligence among the Nursing students and the effect of it on the quality of nursing education and other clinical outcomes. Methodology: A review of the nursing literature was conducted through an initial search of the computerized databases of CINAHL, Pub Med, Google Scholar and Medline with full text. The initial search identified 1500 papers. The selected search criteria included English language articles written between 2014 and 2016. Fifteen studies (quantitative) were included for the review. Findings:The major findings reveal that emotional intelligence has a positive effect on the coping mechanisms, conflict management styles, performance and other factors. The key issues recognized include that the EI skills are rarely promoted in nursing curricula and a positive and nonjudgmental learning environment is vital for students to effectively learn EI concepts. Conclusion: Therefore there is high possibility for further research in this area as well as the need for careful direction regarding the inclusion of educational strategies in to Nursing education, in order to enhance EI in health care environment.
\end{abstract}

Keywords: Emotional Intelligence, Nursing education and EI, Nursing practice and EI and EI in health care .

\section{Introduction}

Emotional intelligence is important in both personal and professional aspects of life. The concept of EI was adapted over a decade ago by Salovey and Mayer and they have defined it as "The ability to perceive emotions, to access and generate emotions so as to assist thought, to understand emotions and emotional knowledge, and to reflectively regulate emotions so as to promote emotional and intellectual growth". Nursing is a profession which deals with people directly on a day to day basis. Training the nursing students as future professional nurses is always a major concern of the nursing centers globally. The holistic compassionate care which the nurses provides are not only the results of the knowledge based on the disease condition, but also is the outcome of a person's emotional intelligence. This paper has reviewed the literature available on EI among nursing students.

\section{Background}

Traditional nursing education considered GPA or the academic performance as the only positive result of a student nurse(Rohde \& Thompson 2007,Leeson et al. 2008). The preparation for professional nursing practice does not depend on the student's cognitive intelligence alone but also on the control of emotions (Newsome et al. 2000, Rego \& Fernandes 2005). Nurses work involve cognitive and technical skills and needs to work under stressful situation too. The interpersonal relationship between the nurses and patients, as well as with the multidisciplinary team functions optimally when the nurse understands their emotions clearly (Cherry and Jacob, 2011). Nurses with high EI have self-awareness, emotional self-control; are flexible and exhibit empathy with others; therefore can respond properly in such conditions; and provide care without their own emotions taking over (Akerjordet \& Severinsson 2007).

Contemporary nursing practice involves undertaking complex procedures involving not only technical skills, but also holistic care that encompasses the emotional, social and spiritual needs of the patient. Adequate understanding of one's own emotions and others' emotions and the ability to manage stress is of highest priority while working in the health care sector. Various conflict management styles are to be practiced to deal with the complex interpersonal and intrapersonal skills. In a study conducted by Chan, Emily, Sit, and Lau(2013), emotional intelligence was a significant predictor of all five conflict management styles. The higher the emotional intelligence, the more students used integrating, obliging, compromising and dominating, which were considered to be the best conflict management styles. A significant positive relationship was found between emotional intelligence of nursing students and caring behavior, resilience (Cuadra and Famadico, 2013) and self-compassion(Senyuva, Kaya, Isik and Bodur, 2014). 
Many studies were found to be in accordance with the details of predictive relationship between emotional intelligence and the program outcomes like academic performance (Rankin, 2013; Fernandez, Salamonson \& Griffiths, 2012; Beauvais, Stewart, DeNisco,\& Beauvais, 2014) and performance of the nursing students (Kaur \& Jiwan, 2014). Emotional intelligence of adult students can be enhanced and empowered as is required for social and academic adjustments. In a study conducted by Mahalkar, George and Nayak, 2014, students used better coping strategies like positive reappraisal and seeking social support after the EI enhancement program. Modern health care system is rapidly changing and there is increased demands for accountability by nurses and the patient safety is also given the utmost significance to assure the quality of care provided. The concepts of EI are central to clinical practice as nurses need to know how to deal with their own emotions as well as provide psychological support to patients and their families(Fernandez et al.,2012).Hence, to enhance the quality of nursing care, it is recommended to develop these skills among nursing students.

In order to achieve a quality nursing outcome for the students selected for the nursing profession emotional intelligence should be considered as a criterion at the entry level. Ouyang, Sang, Li, \& Peng, (2015), have suggested the introduction of EI interventions in the nursing curricula, which may increase emotional coping resources. It can in turn enhance social skills for nurses, which may benefit their long-term occupational health.

\section{Aim of the Study}

The present review was undertaken in an attempt to systematically examine the published evidence on the level of Emotional Intelligence among the Nursing students and the effect of it on the quality of nursing education and other clinical outcomes. Defining the magnitude of this EI on nursing education will allow effective strategies for imparting it to our nursing students.

Methodology:

A literature review of abstracts and articles, written in English, and published between 2014 and 2016 was conducted. Articles were identified using CINAHL, Pub Med, Google Scholar, and Medline with Full Text. Search terms included "Emotional Intelligence", "Nursing education and EI", "Nursing practice and EI" and "EI in health care". In addition, several other websites were searched based on findings from the research papers or from the Google Scholar search.

\section{Inclusion criteria:}

- Original research articles with primary data

- Studies including Emotional Intelligence among Nursing students

- $\quad$ Published in English between 2014 and 2016

Exclusion criteria:

- Unpublished manuscripts or doctoral dissertations

- Review or opinion articles about Emotional Intelligence in Nursing education

The initial search yielded 1500 papers and items with full text online were 300 which were reviewed for duplication. 200 articles were reviewed based on titles and abstracts and 100 articles were retrieved. 83 articles were excluded based on the inclusion criteria, but they were utilized for writing background information of the article. 15 articles were included after having common consensus of the 2 reviewers. It is presented in figure -1 .

\section{Analysis of the findings}

Two authors reviewed the papers and independently selected the articles eligible for review. If multiple published reports from a same study were available, we included only one with the most detailed information, or published more recently. Data were extracted by 2 investigators and discrepancies were resolved by discussion.

\section{Results}

Fifteen studies fulfilling the inclusion criteria related to Emotional Intelligence were selected for this review. Among these thirteen studies were descriptive studies(Nine descriptive correlation design, three descriptive study, two descriptive comparative study) and One experimental study with one group pre and posttest design. These fifteen studies were conducted in the following countries; United States-5, United Kingdom-1,Turkey-1, India-2, China-1, Spain-1, Hongkong-1, Korea-1, Egypt - 1and Scotland-1.The instruments used in these studies to measure Emotional Intelligence are, BarOn Emotional Quotient Inventory (EQ-i) in 1 study, SEIS (Schutte Emotional Intelligence Scale) in 1 study, Emotional intelligence inventory (EI) by Immanuel Thomas in 1 study, Mayer-Salovey-Caruso Emotional Intelligence Test, in 4 studies, Emotional Intelligence Evaluation Scale developed by Hall in 1 study, EI scale developed by Bradbury graves in 1 study, Wong and Law EI scale in 2 studies, and Trait EI Questionnaire Short form(TEIQUE) in 2 studies. Two studies have used researcher developed Questionnaire for assessing EI. The articles were published between the years 2014-2016. Details of all 15 quantitative studies are shown in Table.1. 


\section{Discussion}

This review has analyzed and synthesized the published literature on emotional intelligence (EI) in nursing students. In the light of Salovey and Mayer's theory, emotional intelligence signifies a type of problem-solving capability comprising emotions (Cote, 2014). Previous literature has drawn a difference between ability measures of emotional intelligence and trait measures of emotional intelligence (Brackett \& Mayer, 2003; Cote, 2014; LaPalme, Wang, Joseph, Saklofske, \& Yan,2016 ; Andrei, Siegling, Aloe, Baldaro, \& Petrides, 2016).There is dearth of information on the impact of EI on Academic success and performance of Nursing students. Major findings of the reviewed literature revealed the following themes; EI and Coping mechanisms, EI and Conflict management styles, EI and Performance and EI and other factors.

\section{EI and Coping Mechanisms:}

It was reported in five studies that, higher EI score was correlating positively with stress coping mechanisms and even EI enhancement program improved their coping strategies like positive reappraisal and seeking social support (Ali, Amorim, \& Chamorro-Premuzic,2009; Mhalkar, 2014; Ruiz- Aranda, Extremera, \& Pineda- Galán, 2014; Beauvais et al, 2014). Interestingly, Por, Bariball, Fitzpatrick \& Roberts, 2010 reported that students who have high emotional intelligence are better at managing the emotions evoked by the demands of their nursing program and, therefore, experience less stress.

\section{EI and Conflict Management Styles:}

Two studies reported that, higher EI nursing students were found to be better in managing the conflicts with various styles (Luo, Lee \& Lau, 2016; Chan, Sit \& Lau, 2014). These findings suggested the incorporation of emotional intelligence into clinical practice and integration of emotional and intellectual data into decisionmaking. Emotional intelligence is significant for the development of nursing leaders to deal with the everchanging landscape of healthcare and to curtail the surge of burnout among professional nurses (Cummings, Hayduk \& Estabrooks, 2005). Features and consequences ascribed to effective nursing leadership and the compassionate nurse-patient relationship such as empathy, self-awareness, motivation, self-control and proficiency in relationships have been closely aligned with emotional intelligence (Akerjordet \& Severinsson, 2008).

\section{EI and Performance:}

In a study done among Midwifery nursing students EI was found to be high (Arbabisarjou, Gorgich, Barfroshan, \& Ghoreishinia, 2016). Students with higher EI were reported to perform better than staff nurses(Schenk \& Harper, 2014). In the study conducted among nursing Interns, Internet addiction levels were lower among students with higher level of EI(Angelidis \& Ibrahim, 2011). Prior literature indicated that emotional intelligence (EI) is a significant indicator of future achievement in every walk of life, as well as academic achievement, and career success among university students (Saarni, 1999; Goleman 1995; Bar-On, 2002; Brackett, Mayer, \& Warner, 2004; Mayer, Roberts, \& Barsade, 2008; Oyewunmi, Osibanjo, \& Adeniji, 2016). A recent systemic review revealed the fact that higher EI is significantly related to better academic success among university students(Hanafi and Noor, 2016). On the contrary, the level of academic and clinical performance was found to be lower among the nursing students with higher EI in the study conducted by Kaur et al.,2014. This is similar to the study conducted among 5Pakistan University postgraduate students revealed that, negative and insignificant association between EI and Academic achievement (Gilani, Waheed, Saleem, \& shoukat, 2015).

Thus, it is important for nurse educators to appreciate the concept of emotional intelligence to be able to provide holistic care to clients. Furthermore, the integration of emotional intelligence concepts in nursing education may offer fresh insights into academic and clinical performance of the nursing students, retention and eventually quality client outcomes. In future association between EI and Academic performance need to be evaluated further with Randomized control trials to ascertain the impact on each other.

\section{EI and other factors:}

Higher level of EI was found among nursing students with high Grade point average (GPA) in a study conducted by Codier et al, 2014. EI was reported to be high among the nursing students of University in Scotland, when it was compared with computing students of the same University. EI was better with increasing age (Snowden, 2015) and was reported high among female students(Arbabisarjou et.al, 2016). Lifestyle behaviors such as well-balanced diet and Exercise Participation was found to be better among nursing students with higher EI (Ali et al, 2016). Recruitment and selection procedures should consider emotional intelligence as a legitimate additional entrance criterion for student nurses (Cheshire, Strickland, Carter, 2014) and further research is required to examine the potential relationship between emotional intelligence and compassionate 
care. Emotional intelligence can be enhanced with appropriate training (Williams and stickley 2010, Cunico et al 2012).

\section{NURSING IMPLICATIONS}

Emotions are essential to creating and maintaining a caring environment in nursing education. The nurse's ability to establish rapport with patients, manage their own emotions, and empathize with patients is essential to providing quality care. Improving emotional intelligence skills may benefit nursing students cope with the emotional demands of the healthcare environment which can be stressful and exhausting and can potentially lead to burnout easily. In recognizing the importance of EI as a prerequisite for effective nursing leadership, competent nursing performance and quality clinical outcomes, the results of these reviewed studies offer support that "undergraduate nursing education must provide a learning environment that emphasizes the importance of emotional intelligence by nurturing and facilitating the development of these qualities" (Rochester, Kilstoff, $\&$ Scott 2005, p. 187). We can conclude that the influence of EI in nursing education can be ascertained in many areas from the reviewed studies. Further Randomized controlled trials can be conducted on EI and Academic performance, Clinical competency etc., among Nursing students.

Regardless of the evidence that EI has a positive impact in Nursing education, EI skills are rarely promoted in nursing curricula (Fernandez, Salamonson, \& Griffiths, 2012). A positive and nonjudgmental learning environment is vital for students to effectively learn EI concepts (Roberts, MacCann, Matthews, \& Zeidner, 2010). EI teaching strategies that have been suggested in the literature are reflection, self-inquiry, narrative, forum theater, the arts, and effective listening skills. As Nurse Educators, we have a responsibility to students, to potential employees, and to the public to prepare nurses for the social and emotional demands of their roles (McQueen, 2004) so they are better able to deal with others confidently, competently, and safely. Educational strategies such as arts-based learning approaches combined with conventional approaches, which can provide more diverse opportunities for students to engage with learning about emotions and develop their capacity for the art of interpersonal interactions (Freshwater and Stickley, 2004) can be introduced in Nursing education. There is a great need for inculcating such educational strategies in to Nursing education, in order to enhance EI in health care environment.

\section{Conclusion}

The purpose of this literature review was to examine the empirical evidence related to emotional intelligence among nursing students. The role of EI on variables such as the stress coping mechanisms, Academic and clinical performance, Conflict management, Lifestyle behavior and Internet addiction. We recommend continued research in these aspects aimed at closing the gaps and expanding knowledge related to emotional intelligence in nursing.

\section{Conflict of Interest}

The authors declare no conflict of interest.

\section{Source of funding:}

This review has not received any funding.

\section{References}

[1] Akerjordet, K., \& Severinsson, E. (2007). Emotional intelligence: a review of the literature with specific focus on empirical and epistemological perspectives. Journal of clinical nursing, 16(8), 1405-1416.

[2] Ali, F., Amorim, I. S., \& Chamorro-Premuzic, T. (2009). Empathy deficits and trait emotional intelligence in psychopathy and Machiavellianism. Personality and Individual Differences, 47(7), 758-762.

[3] Ali, N. S., \& Ali, O. S. (2016). Stress perception, lifestyle behaviors, and emotional intelligence in undergraduate nursing students. Journal of Nursing Education and Practice, 6(10), p16.

[4] Andrei, F., Siegling, A. B., Aloe, A. M., Baldaro, B., \& Petrides, K. V. (2016). The incremental validity of the Trait Emotional Intelligence Questionnaire (TEIQue): A systematic review and meta-analysis. Journal of personality assessment, 98(3), 261-276.

[5] Angelidis, J., \& Ibrahim, N. A. (2011). The impact of emotional intelligence on the ethical judgment of managers. Journal of Business Ethics, 99(1), 111-119.

[6] Arbabisarjou, A., Gorgich, E. A. C., Barfroshan, S., \& Ghoreishinia, G. (2016). The Association of Internet Addiction with Academic Achievement, Emotional Intelligence and Strategies to Prevention of them from Student's Perspectives. International Journal of Humanities and Cultural Studies (IJHCS) ISSN 2356-5926, 3(1), 1656-1666.

[7] Bar-On, R. (2002). EQ-i: Baron emotional quotient inventory: A measure of emotional intelligence: Technical manual. MultiHealth System.

[8] Beauvais, A. M., Stewart, J. G., DeNisco, S., \& Beauvais, J. E. (2014). Factors related to academic success among nursing students: a descriptive correlational research study. Nurse Education Today, 34(6), 918-923.

[9] Brackett, M. A., \& Mayer, J. D. (2003). Convergent, discriminant, and incremental validity of competing measures of emotional intelligence. Personality and social psychology bulletin, 29(9), 1147-1158. 
[10] Brackett, M. A., Mayer, J. D., \& Warner, R. M. (2004). Emotional intelligence and its relation to everyday behaviour. Personality and Individual differences, 36(6), 1387-1402.

[11] Chan, J. C. Y., Sit, E. N. M., \& Lau, W. M. (2014). Conflict management styles, emotional intelligence and implicit theories of personality of nursing students: A cross-sectional study. [Article]. Nurse Education Today, 34, 934-939. doi: 10.1016/j.nedt.2013.10.012

[12] Cheshire, M. H., Strickland, H. P., \& Carter, M. R. (2015). Comparing traditional measures of academic success with emotional intelligence scores in nursing students. Asia-Pacific Journal of Oncology Nursing, 2(2), 99.

[13] Codier, E. E., Kofoed, N. A., \& Peters, J. M. (2015). Graduate- Entry Non- Nursing Students: Is Emotional Intelligence the Difference?. Nursing Education Perspectives, 36(1), 46-47.

[14] Codier, E., \& Odell, E. (2014). Measured emotional intelligence ability and grade point average in nursing students. Nurse Education Today, 34(4), 608-612.

[15] Côté, S. (2014). Emotional intelligence in organizations. Annu. Rev. Organ. Psychol. Organ. Behav., 1(1), $459-488$.

[16] Cuadra, D. S., \& Famadico, L. F. (2013). MALE NURSING STUDENTS'EMOTIONAL INTELLIGENCE, CARING BEHAVIOR AND RESILIENCE. International Journal of Arts \& Sciences, 6(3), 243.

[17] Cummings, G., Hayduk, L., \& Estabrooks, C. (2005). Mitigating the impact of hospital restructuring on nurses: the responsibility of emotionally intelligent leadership. Nursing research, 54(1), 2-12.

[18] Cunico, L., Sartori, R., Marognolli, O., \& Meneghini, A. M. (2012). Developing empathy in nursing students: a cohort longitudinal study. Journal of clinical nursing, 21(13- 14), 2016-2025.

[19] Esin Cerit MSc, R. N., \& Nalan Gordeles Beser PhD, R. N. (2014). Levels of emotional intelligence of nursing students. International Journal of Caring Sciences, 7(3), 936.

[20] Fernandez, R., Salamonson, Y., \& Griffiths, R. (2012). Emotional intelligence as a predictor of academic performance in first- year accelerated graduate entry nursing students. Journal of Clinical Nursing, 21(23-24), 3485-3492.

[21] Freshwater, D., \& Stickley, T. (2004). The heart of the art: emotional intelligence in nurse education. Nursing Inquiry, 11(2), 91-98.

[22] Gilani, N., Waheed, S. A., Saleem, K., \& Shoukat, L. (2015). Do Emotions Affect Academic Achievement in Adulthood? Relationship between Postgraduate Students' Trait Emotional Intelligence and Achievement. The AYER, 2, 37-44.

[23] Goleman, D. P. (1995). Emotional intelligence: Why it can matter more than IQ for character, health and lifelong achievement.

[24] Hanafi, Z., \& Noor, F. (2016). Relationship between Emotional Intelligence and Academic Achievement in Emerging Adults: A Systematic Review. International Journal of Academic Research in Business and Social Sciences, 6(6), 268-290.

[25] Ibrahim, A. F., Akel, D. T., El Fatah, L. A. M. A., \& Abudari, M. O. (2016). Emotional intelligence and internet addiction among nursing interns. Clinical Nursing Studies, 4(1), p70.

[26] Jones-Schenk, J., \& Harper, M. G. (2014). Emotional intelligence: An admission criterion alternative to cumulative grade point averages for prelicensure students. Nurse education today, 34(3), 413-420.

[27] Kaur, S., \& Jiwan, T. (2014). An Exploratory Study to Assess Emotional Intelligence and Performance of Students of Selected Nursing Institute, Ludhiana, Punjab. Asian Journal of Nursing Education and Research, 4(3), 346

[28] LaPalme, M. L., Wang, W., Joseph, D. L., Saklofske, D. H., \& Yan, G. (2016). Measurement equivalence of the Wong and Law Emotional Intelligence Scale across cultures: An item response theory approach. Personality and Individual Differences, 90, 190198.

[29] Luo, W., Lee, K., \& Koh, I. C. H. (2015). Do competitive performance goals and cooperative social goals conflict? A latent interaction analysis. Learning and Individual Differences, 39, 186-192.

[30] Luo, Y. F., Ma, F., \& Li, Y. (2016). Emotional Intelligence and Conflict Management among Nursing Students in China. International Journal of Evidence-Based Healthcare, 14, S17.

[31] Mayer, J. D., Roberts, R. D., \& Barsade, S. G. (2008). Human abilities: Emotional intelligence. Annu. Rev. Psychol., 59, 507-536.

[32] McQueen, A. C. (2004). Emotional intelligence in nursing work. Journal of advanced nursing, 47(1), 101-108.

[33] Mhalkar, V., George, L. S., \& Nayak, A. (2014). Relationship between emotional intelligence and coping strategies among Baccalaureate nursing students: An evaluative study. Indian Journal of Health and Wellbeing, 5(11), 1291.

[34] Newsome, S., Day, A. L., \& Catano, V. M. (2000). Assessing the predictive validity of emotional intelligence. Personality and individual differences, 29(6), 1005-1016.

[35] Ouyang, Z., Sang, J., Li, P., \& Peng, J. (2015). Organizational justice and job insecurity as mediators of the effect of emotional intelligence on job satisfaction: A study from China. Personality and Individual Differences, 76, 147-152.

[36] Oyewunmi, A. E., Osibanjo, A. O., \& Adeniji, A. A. (2016). Emotional Intelligence and Academic Performance of Undergraduates: Correlations, Implications and Interventions. Mediterranean Journal of Social Sciences, 7(1), 509.

[37] Petrides, K. V., Pita, R., \& Kokkinaki, F. (2007). The location of trait emotional intelligence in personality factor space. British Journal of Psychology, 98(2), 273-289.

[38] Por, J., Barriball, L., Fitzpatrick, J., \& Roberts, J. (2011). Emotional intelligence: Its relationship to stress, coping, well-being and professional performance in nursing students. Nurse education today, 31(8), 855-860.

[39] Rankin, B. (2013). Emotional intelligence: enhancing values- based practice and compassionate care in nursing. Journal of advanced nursing, 69(12), 2717-2725.

[40] Roberts, R. D., MacCann, C., Matthews, G., \& Zeidner, M. (2010). Emotional intelligence: Toward a consensus of models and measures. Social and Personality Psychology Compass, 4(10), 821-840.

[41] Rochester, S., Kilstoff, K., \& Scott, G. (2005). Learning from success: improving undergraduate education through understanding the capabilities of successful nurse graduates. Nurse Education Today, 25(3), 181-188.

[42] Rohde, T. E., \& Thompson, L. A. (2007). Predicting academic achievement with cognitive ability. Intelligence, 35(1), 83-92.

[43] Ruiz- Aranda, D., Extremera, N., \& Pineda- Galán, C. (2014). Emotional intelligence, life satisfaction and subjective happiness in female student health professionals: the mediating effect of perceived stress. Journal of psychiatric and mental health nursing, 21(2), 106-113.

[44] Saarni, C. (1999). The development of emotional competence. Guilford Press.

[45] Şenyuva, E., Kaya, H., Işik, B., \& Bodur, G. (2014). Relationship between self- compassion and emotional intelligence in nursing students. International journal of nursing practice, 20(6), 588-596.

[46] Sim, S., \& Bang, M. (2016). Emotional Intelligence, Stress Coping, and Adjustment to College Life in Nursing Students. International Journal of Bio-Science and Bio-Technology, 8(3), 21-32.

[47] Snowden, A., Stenhouse, R., Young, J., Carver, H., Carver, F., \& Brown, N. (2015). The relationship between emotional intelligence, previous caring experience and mindfulness in student nurses and midwives: a cross sectional analysis. Nurse education today, 35(1), 152-158.

[48] Williams, J., \& Stickley, T. (2010). Empathy and nurse education. Nurse education today, 30(8), $752-755$. 
Figure.1 Flow chart showing methodological pathway
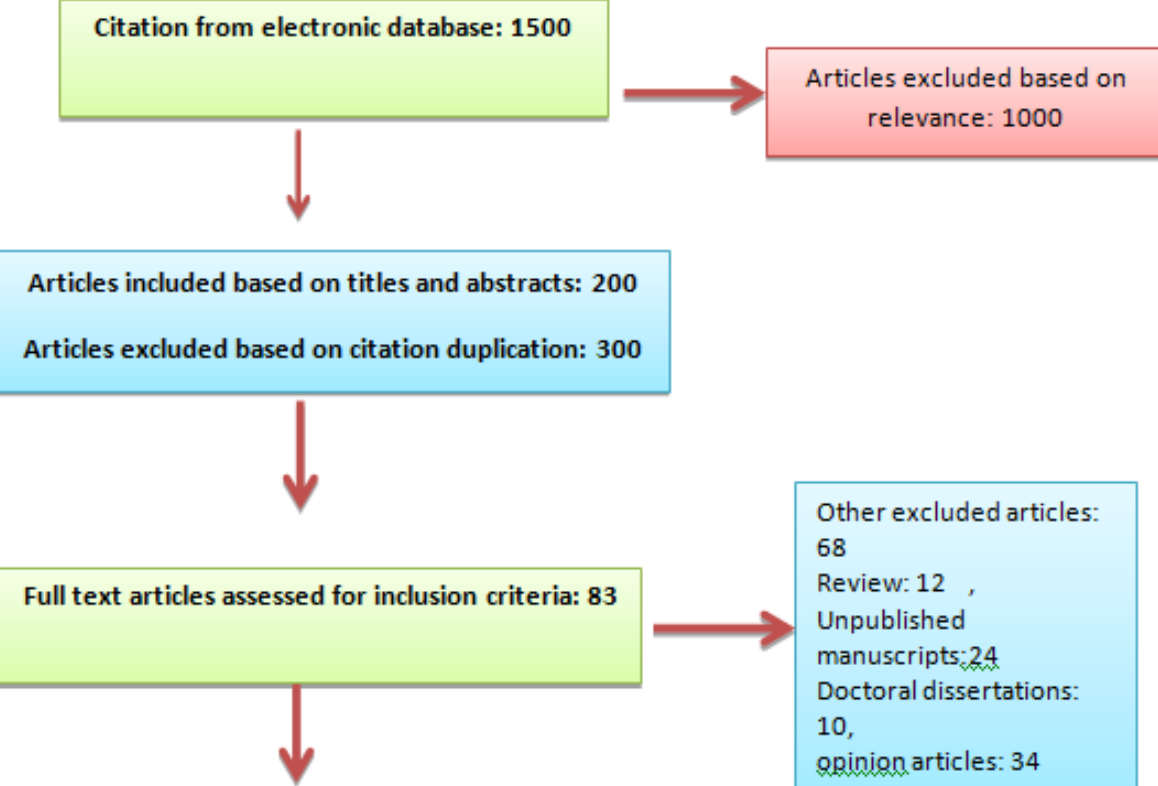

Other excluded articles: 68 Review: 12

Unpublished manuscripts: 24

Doctoral dissertations:

10 ,

Qpinion articles: 34 


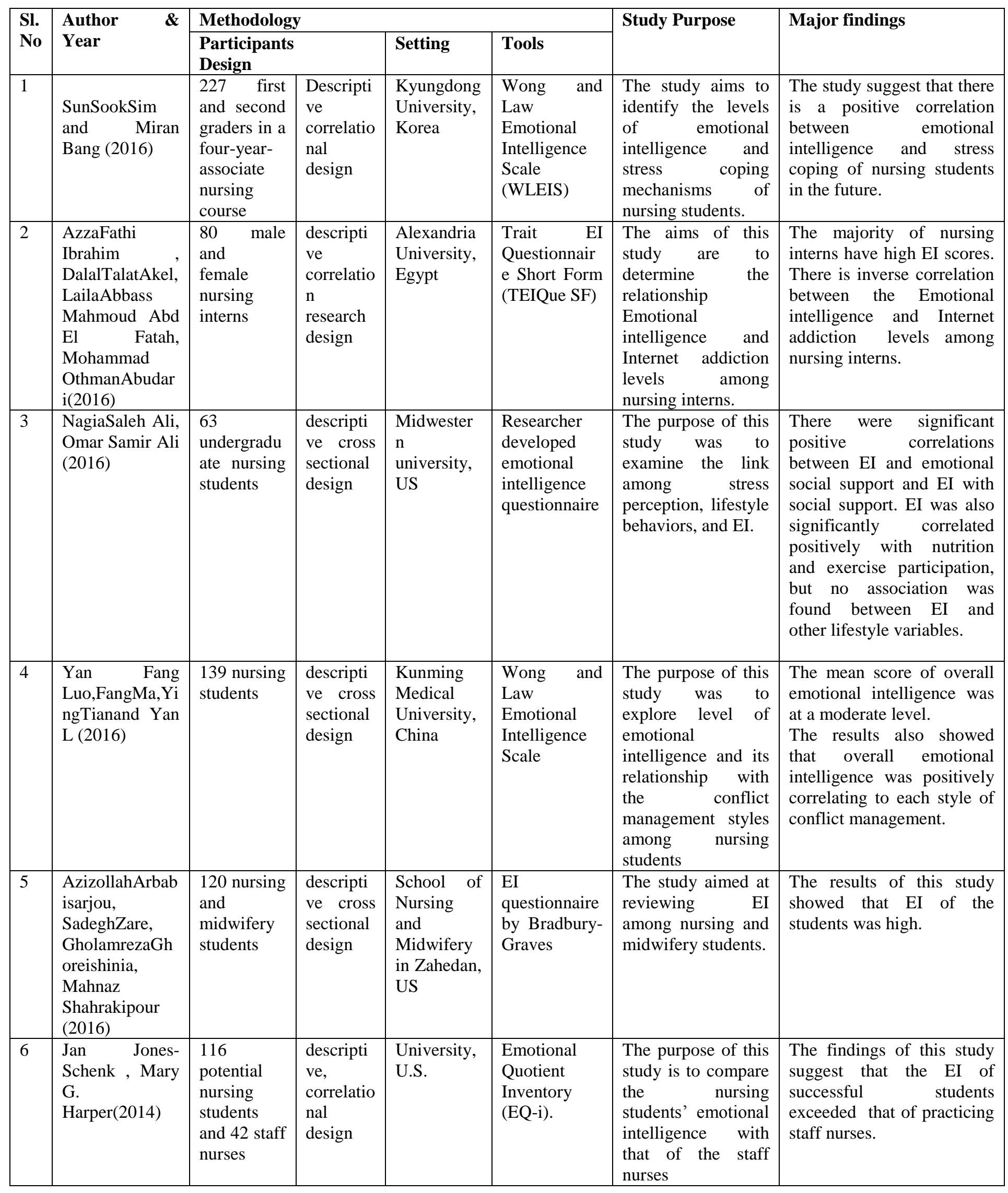


Emotional Intelligence among Nursing Students - An Integrated Review

\begin{tabular}{|c|c|c|c|c|c|c|c|}
\hline 7 & 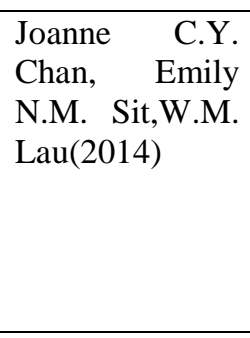 & $\begin{array}{l}568 \text { second } \\
\text { and Third } \\
\text { level } \\
\text { Undergrad } \\
\text { uate } \\
\text { nursing } \\
\text { students }\end{array}$ & $\begin{array}{l}\text { cross } \\
\text { sectional } \\
\text { quantitati } \\
\text { ve } \\
\text { survey }\end{array}$ & $\begin{array}{l}\text { University } \\
\text { in } \\
\text { Hong Kong }\end{array}$ & $\begin{array}{l}\text { The Schutte } \\
\text { Emotional } \\
\text { Intelligence } \\
\text { Scale (SEIS). }\end{array}$ & $\begin{array}{l}\text { This study aimed at } \\
\text { predicting factors } \\
\text { associated with } \\
\text { undergraduate } \\
\text { nursing students, } \\
\text { conflict } \\
\text { management styles } \\
\text { in the clinical area }\end{array}$ & $\begin{array}{l}\text { Emotional intelligence was } \\
\text { a significant predictor of all } \\
\text { five conflict management } \\
\text { styles. }\end{array}$ \\
\hline 8 & $\begin{array}{l}\text { Austyn } \\
\text { Snowden , } \\
\text { Rosie } \\
\text { Stenhouse, , } \\
\text { Jenny Young, } \\
\text { Hannah Carver } \\
\text {, Fiona Carver, } \\
\text { Norrie Brown } \\
(2015)\end{array}$ & $\begin{array}{l}870 \text { nursing } \\
\text { and } \\
\text { midwifery } \\
\text { students } \\
\text { and } 68 \\
\text { computing } \\
\text { students }\end{array}$ & $\begin{array}{l}\text { Cross } \\
\text { sectional } \\
\text { element } \\
\text { of } \\
\text { longitudi } \\
\text { nal study }\end{array}$ & $\begin{array}{l}\text { University } \\
\text { programs at } \\
\text { two } \\
\text { Scottish } \\
\text { universities }\end{array}$ & $\begin{array}{l}\text { Trait } \\
\text { Emotional } \\
\text { Intelligence } \\
\text { Questionnair } \\
\text { e (TEIQue- } \\
\text { SF) and } \\
\text { Schutte's } \\
\text { (1998) } \\
\text { Emotional } \\
\text { Intelligence } \\
\text { Scale (SEIS). }\end{array}$ & $\begin{array}{l}\text { To explore the } \\
\text { relationship } \\
\text { between EI, gender, } \\
\text { age, programe of } \\
\text { study, }\end{array}$ & $\begin{array}{l}\text { Emotional intelligence } \\
\text { increased with age. Women } \\
\text { had significantly higher } \\
\text { emotional intelligence than } \\
\text { men. Distributions of } \\
\text { TEIQ-SF scores and SEIS } \\
\text { scores shows that } \\
\text { computing students scored } \\
\text { low in comparison to all the } \\
\text { nursing student groups. }\end{array}$ \\
\hline 9 & $\begin{array}{l}\text { VithobaMhalka } \\
\text { r, Linu Sara } \\
\text { George, } \\
\text { AshaNayak } \\
(2014)\end{array}$ & $\begin{array}{l}74 \quad \text { first } \\
\text { year } \\
\text { nursing } \\
\text { students }\end{array}$ & $\begin{array}{l}\text { Onegrou } \\
\mathrm{p} \text { pretest } \\
\text { posttest } \\
\text { design }\end{array}$ & $\begin{array}{l}\text { College of } \\
\text { Nursing, } \\
\text { India }\end{array}$ & $\begin{array}{l}\text { emotional } \\
\text { intelligence } \\
\text { inventory } \\
\text { (EI) by } \\
\text { Immanuel } \\
\text { Thomas and } \\
\text { coping } \\
\text { strategies } \\
\text { scale }\end{array}$ & $\begin{array}{l}\text { This study aimed at } \\
\text { assessing the EI of } \\
\text { nursing students as } \\
\text { well as the coping } \\
\text { strategies used by } \\
\text { them before and } \\
\text { after the EI } \\
\text { enhancement } \\
\text { program. }\end{array}$ & 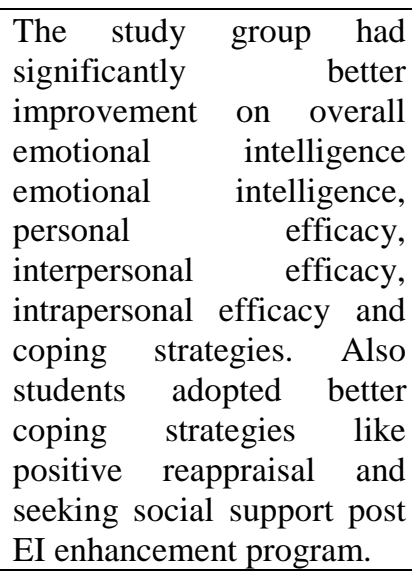 \\
\hline 10 & $\begin{array}{lr}\text { Estelle } & \text { Codier, } \\
\text { Ellen } & \text { Odell } \\
(2014) & \end{array}$ & $\begin{array}{l}72 \\
\text { undergradu } \\
\text { ate student } \\
\text { nurse } \\
\text { volunteers }\end{array}$ & $\begin{array}{l}\text { Correlati } \\
\text { onal } \\
\text { study }\end{array}$ & $\begin{array}{l}\text { school of } \\
\text { nursing in } \\
\text { the south } \\
\text { central } \\
\text { region } \\
\text { of the } \\
\text { United } \\
\text { States }\end{array}$ & $\begin{array}{l}\text { Mayer- } \\
\text { Salovey- } \\
\text { Caruso } \\
\text { Emotional } \\
\text { Intelligence } \\
\text { Test, } \\
\text { version 2 }\end{array}$ & $\begin{array}{l}\text { To measure the } \\
\text { relationship } \\
\text { between emotional } \\
\text { intelligence ability } \\
\text { and grade point } \\
\text { average of first year } \\
\text { nursing students }\end{array}$ & $\begin{array}{l}\text { Total emotional intelligence } \\
\text { scores correlated positively } \\
\text { with the grade point } \\
\text { average of the students. }\end{array}$ \\
\hline 11 & $\begin{array}{l}\text { SukhbirKaur\& } \\
\text { TrizaJiwan(201 } \\
\text { 4) }\end{array}$ & $\begin{array}{l}150 \text { nursing } \\
\text { students. }\end{array}$ & $\begin{array}{l}\text { Correlati } \\
\text { onal } \\
\text { study }\end{array}$ & $\begin{array}{l}\text { College of } \\
\text { Nursing, } \\
\text { India }\end{array}$ & $\begin{array}{l}\text { Self- reported } \\
\text { Emotional } \\
\text { intelligence } \\
\text { scale. }\end{array}$ & $\begin{array}{l}\text { To assess the } \\
\text { emotional } \\
\text { intelligence and the } \\
\text { levels of } \\
\text { performance of } \\
\text { nursing students. }\end{array}$ & $\begin{array}{l}\text { There was weak negative } \\
\text { correlation between } \\
\text { emotional intelligence and } \\
\text { the levels of performance } \\
\text { indicating that if emotional } \\
\text { intelligence increases, } \\
\text { performance decreases. }\end{array}$ \\
\hline 12 & $\begin{array}{l}\text { Estelle E. } \\
\text { Codier, Nancy } \\
\text { A. Kofoed, and } \\
\text { Judith M. } \\
\text { Peters (2015) }\end{array}$ & $\begin{array}{l}217 \\
\text { students- } \\
57 \text { students } \\
\text { from } \\
\text { graduate } \\
\text { nursing } \\
\text { programs } \\
\text { for non- } \\
\text { nurses }\end{array}$ & $\begin{array}{l}\text { Compara } \\
\text { tive } \\
\text { study }\end{array}$ & Hawaii, US & $\begin{array}{l}\text { Mayer- } \\
\text { Salovey- } \\
\text { Caruso } \\
\text { Emotional } \\
\text { Intelligence } \\
\text { test } \\
\text { (MSCEIT), } \\
\text { version } \\
2 .\end{array}$ & $\begin{array}{l}\text { To compare the } \\
\text { measured emotional } \\
\text { intelligence ability } \\
\text { between students in } \\
\text { a GPNNN program } \\
\text { with students in } \\
\text { traditional schools } \\
\text { of nursing }\end{array}$ & $\begin{array}{l}\text { The findings highlighted } \\
\text { only one significant } \\
\text { difference among the } \\
\text { schools could be found that } \\
\text { is, in the "ability to } \\
\text { understand emotions". }\end{array}$ \\
\hline
\end{tabular}




\begin{tabular}{|c|c|c|c|c|c|c|c|}
\hline & & $\begin{array}{l}\text { GPNNN }) \\
\text { program } \\
.160 \\
\text { Traditional } \\
\text { nursing } \\
\text { students } \\
\end{array}$ & & & & & \\
\hline 13 & $\begin{array}{l}\text { EsinCerit\&Nala } \\
\text { nGordelesBeser } \\
,(2014) .\end{array}$ & $\begin{array}{l}183 \text { nursing } \\
\text { school } \\
\text { students }\end{array}$ & $\begin{array}{l}\text { Descripti } \\
\text { ve study }\end{array}$ & $\begin{array}{l}\text { School of } \\
\text { Nursing, } \\
\text { Turkey. }\end{array}$ & $\begin{array}{l}\text { Emotional } \\
\text { Intelligence } \\
\text { Evaluation } \\
\text { Scale } \\
\text { developed by } \\
\text { Hall in } 1999 .\end{array}$ & $\begin{array}{l}\text { To measure the } \\
\text { emotional } \\
\text { intelligence levels } \\
\text { of nursing students }\end{array}$ & $\begin{array}{l}\text { The mean score of the } \\
\text { nursing students were found } \\
\text { to be normal. It was not } \\
\text { associated with any } \\
\text { demographic variables like } \\
\text { age, gender and marital } \\
\text { status. }\end{array}$ \\
\hline 14 & $\begin{array}{l}\text { D.Ruiz - } \\
\text { Aranda, } \\
\text { N. Extremera\& } \\
\text { C. Pineda - } \\
\text { Galán(2014) }\end{array}$ & $\begin{array}{l}\text { Female } \\
\text { nursing } \\
\text { students } \quad(n \\
=264)\end{array}$ & $\begin{array}{l}\text { Compara } \\
\text { tive } \\
\text { study }\end{array}$ & $\begin{array}{l}\text { University } \\
\text { in Spain }\end{array}$ & $\begin{array}{l}\text { Mayer- } \\
\text { Salovey- } \\
\text { Caruso } \\
\text { Emotional } \\
\text { Intelligence } \\
\text { Test } \\
\text { (MSCEIT) }\end{array}$ & $\begin{array}{l}\text { To examine the } \\
\text { relationship } \\
\text { between emotional } \\
\text { intelligence (EI) } \\
\text { and well-being } \\
\text { indicators and to } \\
\text { assess the influence } \\
\text { of perceived stress. }\end{array}$ & $\begin{array}{l}\text { The findings showed that } \\
\text { higher emotional } \\
\text { intelligence was associated } \\
\text { with increase in the well- } \\
\text { being of students by } \\
\text { reducing the experience of } \\
\text { stress. }\end{array}$ \\
\hline 15 & $\begin{array}{l}\text { Audrey M. } \\
\text { Beauvais, Julie } \\
\text { G. Stewart , } \\
\text { Susan DeNisco } \\
\text {, John E. } \\
\text { Beauvais } \\
(2014)\end{array}$ & $\begin{array}{l}124 \text { nursing } \\
\text { students }\end{array}$ & $\begin{array}{l}\text { descripti } \\
\text { ve } \\
\text { correlatio } \\
\text { nal } \\
\text { design }\end{array}$ & $\begin{array}{l}\text { Catholic } \\
\text { university } \\
\text { in New } \\
\text { England, } \\
\text { UK }\end{array}$ & $\begin{array}{l}\text { Mayer- } \\
\text { Salovey- } \\
\text { Caruso } \\
\text { Emotional } \\
\text { Intelligence } \\
\text { Test } \\
\text { (MSCEIT), }\end{array}$ & $\begin{array}{l}\text { The purpose of the } \\
\text { correlational study } \\
\text { was to describe the } \\
\text { relationship } \\
\text { between emotional } \\
\text { intelligence, } \\
\text { psychological } \\
\text { empowerment, } \\
\text { resilience, spiritual } \\
\text { well-being, and } \\
\text { academic success in } \\
\text { undergraduate } \\
\text { and graduate } \\
\text { nursing students. }\end{array}$ & $\begin{array}{l}\text { There was a significant } \\
\text { positive relationship found } \\
\text { between EI and } \\
\text { psychological } \\
\text { empowerment, resilience, } \\
\text { spiritual well-being and } \\
\text { also academic success in } \\
\text { the students }\end{array}$ \\
\hline
\end{tabular}

